Article

\title{
The influence of solution annealing temperature on the properties of Lean Duplex 2101 welded joints in tubes
}

\author{
Grzegorz Rogalskii ${ }^{1, *}$, Aleksandra Świerczyńska ${ }^{1}$, Dariusz Fydrych ${ }^{1}$, Michał Landowski ${ }^{1}$ \\ ${ }^{1}$ Gdańsk University of Technology, Poland \\ Dr. Aleksandra Świerczyńska; aleswier@pg.edu.pl \\ Prof. Dariusz Fydrych; darfydry@pg.edu.pl \\ Dr. Michał Landowski; miclando@pg.edu.pl \\ * Correspondence: Dr. hab. Grzegorz Rogalski; grzegorz.rogalski@pg.edu.pl
}

\begin{abstract}
The article presents a technology of TIG longitudinal welding without filler material (142) of heat exchanger tubes made of Lean Duplex 2101. The results of studies on the effect of heat treatment (solution annealing) on tensile strength, plasticity, delta ferrite and the structure of smooth tubes are shown. It was found, that the change in solution annealing temperature across the tested range has an impact on mechanical properties of welded tubes and the most advantageous solution annealing temperature $\left(1050^{\circ} \mathrm{C}\right)$ was determined.
\end{abstract}

Keywords: tubes; TIG welding (142); post weld heat treatment; Lean Duplex 2101; properties

\section{Introduction}

Tubes are semi-finished products that are used in the construction of various types of equipment,

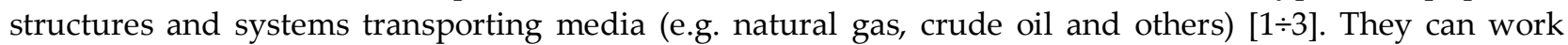
in various operating conditions, which depends on the intended use of the structure. For this reason, they are given appropriate requirements with regard to, among other things, geometric dimensions (tolerance of wall thickness and diameter, ovality and length), strength properties ( $R \mathrm{~m}, \mathrm{Rp} 0.2, \mathrm{~A} 50$ ), weldability (welding, brazing) and possibility of working under certain operating conditions (e.g. work in a medium with higher concentration of $\mathrm{Cl}^{-}$chlorides). The mentioned requirements determine the selection of tubes with the appropriate chemical composition, which translates into a specific material group and species. These semi-finished products have been classified in many subject standards, which enables their proper identification in relation to the requirements set for them. Examples of standards are PN-EN 10217-7 (Welded steel tubes for pressure purposes. Technical delivery conditions. Part 7: Stainless steel tubes), PNEN 10216-5 (Seamless steel tubes for pressure purposes. Technical delivery conditions. Part 5: Stainless steel tubes) and SA 789 (Specification for seamless and welded ferritic/austenitic stainless steel, tubing for general service). Tubes used in various industrial sectors are manufactured as seamless or with a seam [3]. They are subject to a production cycle, which must take into account all elements that allow obtaining the required properties. In the case of tubes with a seam, welding is usually used, which is or can be associated with other processes, e.g. post weld heat treatment (PWHT). This situation can be encountered in the production of tubes made of high-alloy austenitic stainless steel, where the heat treatment consisting of solution annealing is applied immediately after welding [4,5]. The study of the effect of this process on the

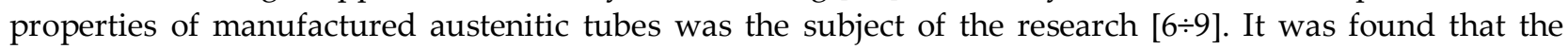
change in solution annealing temperature even in the range acceptable by the product standard has an impact on the strength and plastic properties of the tested tubes.

An important group of products that is made from a tube system in various geometric configurations are tubular and shell-and-tube heat exchangers. Due to the nature of the work (e.g. as heaters, condensers or evaporators), they must meet very specific requirements in relation to the working medium, operating temperature and pressure [10 $\div 12]$. This determines the selection of the right type of material. The spectrum of materials is very wide ranging from unalloyed and alloy steels for work at elevated temperatures (e.g. P265GH, P355GH, 16Mo3, P22, P91) through high-alloy stainless austenitic steels (AISI 304, AISI 316L, AISI 321) and ending with titanium and its alloys (e.g. Gr. 1, Gr. 2, Gr. 5), nickel and its alloys (e.g. Incoloy $800 \mathrm{H}$, Inconel 625, Alloy C-276) and other less common construction materials, e.g. UNS R05200 tantalum or UNS R60702 zirconium [4,5,10,11]. The use of such a wide group of construction materials in connection with the relevant manufacturing technologies, including welding, is to ensure adequate durability 
and reliability. Research on welding technologies and service life of welded joints of the aforementioned

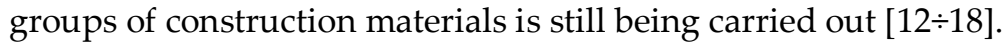

One of the dynamically developing material groups are steels with a duplex ferritic-austenitic

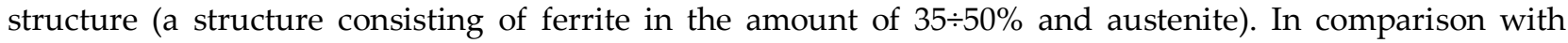
stainless steels with austenitic structure, they are characterized by higher mechanical strength $(\mathrm{Re}>450 \mathrm{MPa})$ and very good corrosion resistance, especially for pitting and stress corrosion of SCC type (Stress Corrosion Cracking) in the chloride environment. In addition, like stainless austenitic steels, they are characterized by good weldability, while maintaining the appropriate technological regime obtained by qualifying the welding technology. Undoubted advantages of this material group include also good erosion and abrasion resistance as well as good machinability, which is important from the point of view of prefabrication of elements for welding. Despite the many advantages, these steels are however sensitive to the effects of the welding thermal cycle, which affects the structural changes. The high joint cooling rate usually leads to an increase in the ferrite content in the structure, the precipitation of chromium nitrides, the segregation of alloying elements between the ferritic and austenitic phases causing the formation of micro-areas depleted in $\mathrm{Cr}$ and $\mathrm{Ni}$. In turn, the effect of reduced cooling rates may be the separation of intermetallic phases (e.g. sigma phase) - hence the limitation of the heat input in the range of $1.5 \div 2.0 \mathrm{~kJ} / \mathrm{mm}$ and the loss of nitrogen from root runs, which usually leads to reduce the share of austenite in the steel structure $[19,20]$. However, the presented difficulties can be eliminated by appropriate correlation between the main variables (e.g. type of the filler material, the heat input, the geometry of the welding groove, the type of shielding gases and others). The number of available literature sources referring to the weldability of duplex steel is very wide [21 $\div 25]$. This helps eliminate many hazards in the welding process. A comparison of chemical composition and strength properties for selected grades of austenitic and duplex stainless steels are presented in tables I and II.

Table I. Comparison of the chemical composition of the duplex steel LDX 2101 and other grades of stainless steels, wt $\%$, acc. to PN-EN 10088-2 and SA 240

\begin{tabular}{cccccccccc}
\hline $\begin{array}{c}\text { Grade } \\
\text { of the steel }\end{array}$ & $\begin{array}{c}\text { Wr. } \\
\text { No. }\end{array}$ & $\begin{array}{c}\text { Designation } \\
\text { ASTM/UNS }\end{array}$ & C & N & Cr & Ni & Mo & Others & PRE \\
\hline LDX 2101 & 1.4162 & S32101 & 0.03 & 0.22 & 21.5 & 1.5 & 0.3 & 5 Mn & 26 \\
2205 & 1.4462 & S32205 & 0.02 & 0.17 & 22.0 & 5.7 & 3.1 & - & 35 \\
2507 & 1.4410 & S32750 & 0.02 & 0.27 & 25.0 & 7.0 & 4.0 & - & 43 \\
304L & 1.4307 & 304L & 0.02 & - & 18.1 & 8.1 & - & - & 18 \\
316L & 1.4404 & 316L & 0.02 & - & 17.2 & 10.1 & 2.1 & - & 25 \\
\hline
\end{tabular}

Pitting resistance equivalent, $\mathrm{PRE}=\mathrm{Cr}+3.3 \times \% \mathrm{Mo}+16 \times \% \mathrm{~N}$

Table II. Comparison of selected properties and the temperature of solution annealing for LDX 2101 and other grades of stainless steels acc. to EN 10088-2, SA 789

\begin{tabular}{|c|c|c|c|c|c|c|}
\hline $\begin{array}{c}\text { Grade } \\
\text { of the steel }\end{array}$ & Wr. No. & $\begin{array}{l}\text { Designation } \\
\text { ASTM/UNS }\end{array}$ & $\begin{array}{c}\mathbf{R}_{\mathrm{p} 0,2} \\
{[\mathrm{MPa}]}\end{array}$ & $\begin{array}{c}\mathbf{R m}_{\mathrm{m}} \\
{[\mathrm{MPa}]}\end{array}$ & $\begin{array}{l}\text { A80 } \\
{[\%]}\end{array}$ & $\begin{array}{c}\text { Solution } \\
\text { annealing } \\
\text { temperature }\left[{ }^{\circ} \mathrm{C}\right]\end{array}$ \\
\hline LDX 2101 & 1.4162 & S32101 & $\min .450$ & $650 \div 800$ & $\min .30$ & $1020 \div 1080$ \\
\hline 2205 & 1.4462 & S32205 & $\min .480$ & $660 \div 950$ & $\min .25$ & $1020 \div 1100$ \\
\hline 2507 & 1.4410 & S32750 & $\min .550$ & $750 \div 1000$ & $\min .15$ & $1040 \div 1120$ \\
\hline 304L & 1.4307 & 304L & $\min .220$ & $520 \div 670$ & $\min .45$ & $1000 \div 1100$ \\
\hline 316L & 1.4404 & 316L & $\min .240$ & $530 \div 680$ & $\min .40$ & $1030 \div 1100$ \\
\hline
\end{tabular}

The presented material group, due to its advantages, was used in the construction of shell-and-tube heat exchangers. One of the important elements of these devices is the coil, which is made of a bundle of tubes. An example of a coil is shown in figure 1.

The tubes that will be subjected to the plastic working process, e.g. in the coil winding process, have to be heat treated after welding. In the case of duplex steels, as for austenitic stainless steels, solution annealing is used. This process consists in bringing the material to a high temperature depending on the type of steel processed (temperature ranges are given in product standards) and very fast cooling most often in water or a special emulsion. Such treatment improves the plasticity (structure of homogeneous austenite) and gives the possibility of obtaining a structure without precipitation of chromium carbides $\left(\mathrm{M}_{23} \mathrm{C}_{6}\right)$ most $_{\text {often }}$ in the form of a grid at the grain boundaries. The latter feature protects the steel against the progress 
of intergranular corrosion in the joint area. Properly carried out heat treatment allows to obtain a structure that translates into very good plastic properties while maintaining adequate corrosion resistance and tensile strength. However, it should be remembered that for some temperature-technological associations, this treatment may lead to a reduction in tensile strength and in the case of duplex steels, changes in hardness and ferrite content.

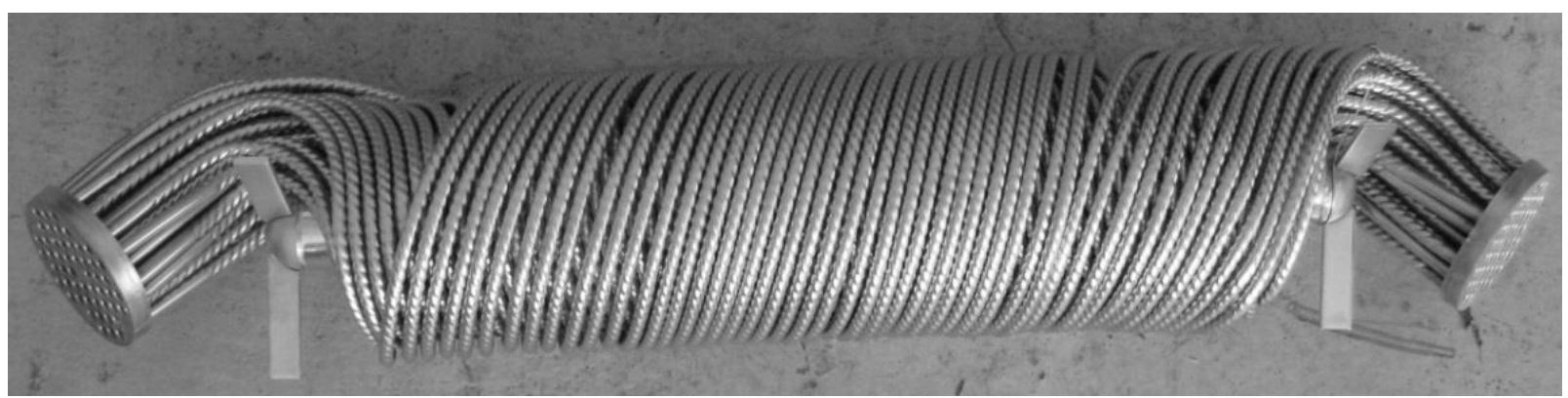

Fig. 1. Coils made of welded AISI 321 steel tubes [24]

\section{Aim of the work}

The aim of the work was to determine the effect of the temperature of solution annealing in the range from $1000{ }^{\circ} \mathrm{C}$ to $1100{ }^{\circ} \mathrm{C}$ on the properties of Lean Duplex 2101 steel tubes with geometrical dimensions of $\varnothing 25.0 \times 1.0 \mathrm{~mm}$ produced using the TIG welding process (142).

Table III. Chemical composition of LDX 2101 duplex steels, wt.\% and mechanical properties acc. to certificate 3.1

\begin{tabular}{|c|c|c|c|c|c|c|c|c|c|}
\hline \multicolumn{10}{|c|}{ Chemical composition } \\
\hline C & Si & Mn & $\mathbf{P}$ & $\mathrm{S}$ & $\mathbf{N}$ & $\mathrm{Cr}$ & Mo & $\mathrm{Ni}$ & $\mathrm{Cu}$ \\
\hline 0.021 & 0.67 & 4.79 & 0.026 & 0.001 & 0.21 & 21.4 & 0.17 & 1.49 & 0.32 \\
\hline \multicolumn{10}{|c|}{ Mechanical properties } \\
\hline $\mathrm{Rp}_{0.2}$ [MPa] & \multicolumn{2}{|c|}{$\mathrm{R}_{\mathrm{m}}[\mathrm{MPa}]$} & $\mathbf{A}_{50}$ & & \multicolumn{2}{|c|}{$\mathbf{A}_{80}[\%]$} & \multirow{3}{*}{\multicolumn{3}{|c|}{$\begin{array}{l}\text { Roughness } \mathrm{R}_{\mathrm{a}}=0,24 \mu \mathrm{m} \\
\text { Spectroscopic verification }\end{array}$}} \\
\hline 558 & \multirow{2}{*}{\multicolumn{2}{|c|}{$\begin{array}{l}700 \\
900\end{array}$}} & \multirow{2}{*}{\multicolumn{2}{|c|}{$\begin{array}{l}38 \\
35\end{array}$}} & \multicolumn{2}{|c|}{30} & & & \\
\hline 559 & & & & & \multicolumn{2}{|c|}{31} & & & \\
\hline
\end{tabular}

\section{Own research}

\section{Material and welding technology}

The work is a continuation of research conducted in the field of determining the effect of the temperature of solution annealing on the properties of tubes produced by welding [6,7]. The tubes are made of Lean Duplex LDX 2101 steel (Wr no.: 1.4162, UNS S32101), from a tape with a width that allows obtaining an external diameter of $25 \mathrm{~mm}$ and a wall thickness of $1 \mathrm{~mm}$. Tubes with a smooth surface were made for the test. The chemical composition and strength properties of the steel used are shown in Table III according to the certificate of acceptance 3.1 according to PN-EN 10204. Immediately after welding, the samples were subjected to solution annealing in water from temperatures of $1000{ }^{\circ} \mathrm{C}, 1050{ }^{\circ} \mathrm{C}, 1100{ }^{\circ} \mathrm{C}$. The purpose of the heat treatment was to improve the plastic properties of the tubes and to protect them against intergranular corrosion. Due to the continuous method of producing tubes (tubes are moving longitudinally),

a calibrated type UNO U1 600/1600 C-L10-A10 pyrometer was used for temperature measurement.

The achievement of the set goal was accomplished based on the following research plan:

1. Development of welding technology (WPS - welding procedure specification).

2. Execution of test joints and preparation of samples for testing according to the prepared test plan (Table IV).

3. Performing non-destructive tests:

- visual tests (VT);

- eddy current tests (ET);

- penetrant tests (PT);

4. Performing destructive tests:

- static tensile tests; 
- flattening tests;

- flanging tests;

- macroscopic and microscopic metallographic examinations;

- measurements of the delta ferrite content.

Table IV. List of specimens prepared for testing

\begin{tabular}{ccc}
$\begin{array}{c}\text { Designation of the } \\
\text { sample }\end{array}$ & $\begin{array}{c}\text { Solution annealing temperature } \\
{\left[{ }^{\circ} \mathrm{C}\right]}\end{array}$ & Type of tests \\
\hline $\mathrm{R} 1$ & 1000 & \\
$\mathrm{R} 2$ & 1050 & Static tensile tests \\
$\mathrm{R} 3$ & 1100 & \\
$1-1,1-2,1-3$ & 1000 & Flanging tests \\
$2-1,2-2,2-3$ & 1050 & \\
$3-1,3-2,3-3$ & 1100 & \\
$1-4,1-5,1-6$ & 1000 & \\
$2-4,2-5,2-6$ & 1050 & Flattening tests \\
$3-4,3-5,3-6$ & 1100 & Macro/microscopic \\
1 & 1000 & examinations \\
2 & 1050 & \\
\hline
\end{tabular}

Before starting the WPS development, relevant variables were determined that affect the course of the manufacturing process. They include:

1. Base material grade: Lean Duplex 2101 steel (1.4162); material group according to TR ISO 15608: 10.1.

2. Geometrical dimensions of the tube: $\varnothing=25 \mathrm{~mm}, \mathrm{t}=1 \mathrm{~mm}$.

3. Type of joint and weld: single-bead longitudinal butt weld (BW), butt joint.

4. Type of welding: automatic welding.

5. Welding method: TIG (142) without filler material.

6. Welding position: PA.

7. Current type and polarity: direct current, negative polarity, DC (-).

8. Shielding gases: backing gas N1 according to EN ISO 14175, from the side of the welding (shielding gas) torch N2 in EN ISO 14175.

9. Heat treatment: solution annealing, $1000{ }^{\circ} \mathrm{C}, 1050^{\circ} \mathrm{C}, 1100^{\circ} \mathrm{C}$.

An automatic production line consisting of the following elements was used for the production of the tubes: pulling and forming rollers, welding chambers, TIG welding equipment with accessories, heat treatment unit, eddy current control unit (with material magnetization system), cutting and storage unit.

In order to determine the welding parameters enabling the execution of joints characterized by the geometry which corresponds to the quality level B according to EN ISO 5817, a series of technological welding tests was carried out. For the applied process (142) and the welding speed imposed by the manufacturer $(2.4 \mathrm{~m} / \mathrm{min})$, it was found that the optimal current parameters are: $I=200 \div 210 \mathrm{~A}, \mathrm{U}=17 \mathrm{~V}$. The geometry of the elements before and after welding is shown in figure 2.

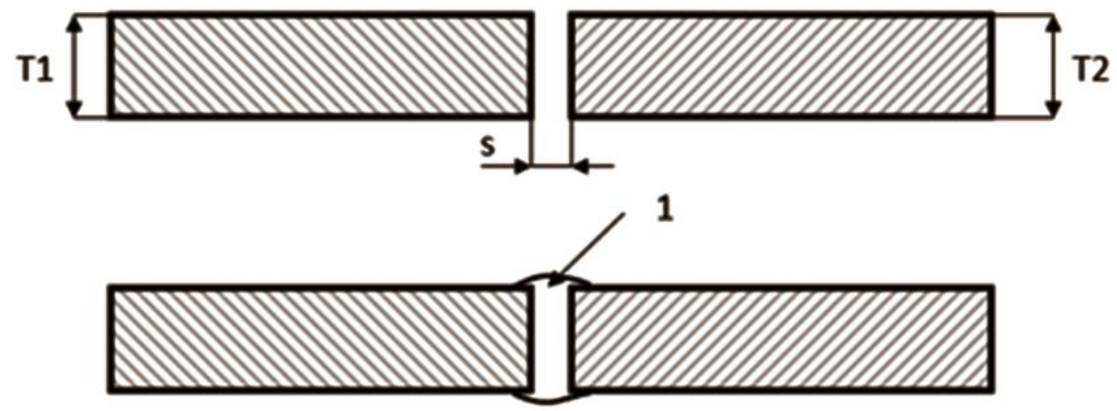

Fig. 2. The geometry of the elements before and after the welding process, where: $\mathrm{T} 1=\mathrm{T} 2=1 \mathrm{~mm}, \mathrm{~s}=0 \mathrm{~mm}$, 1 - weld 
The shielding gases used are an important element of the developed technology. Based on our own experience, the use of shielding gas I1 acc. to EN ISO 14175 (99.999\% Ar) as a protection of the welding pool (from the torch side) and baking forming gas often lead to nitrogen loss on both sides of the weld, which is related to the pursuance of the system to achieve equilibrium. This leads to an increase in the ferrite content beyond the required acceptance criteria (e.g. according to ASTM E562 and NORSOK M-601 it is 30-70\% of ferrite in the welded joint). To prevent this hazard, the following gases were used: from the torch side N2 according o EN ISO $14175\left(\mathrm{Ar}+2 \% \mathrm{~N}_{2}\right)$, from the root side N1 according to EN ISO $14175\left(100 \% \mathrm{~N}_{2}\right)$. This usually leads to a reduction in nitrogen losses from both the weld face and its root. Nitrogen is absorbed by the weld, which translates into obtaining a balanced content in the weld metal. This in turn allows to obtain a high content of austenitic structure. The own experiments are confirmed in the results of tests [25] conducted using the mentioned gases and with the addition of hydrogen in the mixture (up to $10 \% \mathrm{H}_{2}$ ). The balanced content of ferrite and austenite translates into high strength properties and very good corrosion resistance.

\section{Non-destructive testing}

Visual tests were carried out on all samples in accordance with EN ISO 17637. No welding defects were found on the surface of the tested samples thus they were found to correspond to the quality level B according to PN-EN ISO 5817. However, it should be remembered that the solution annealing process affects the colour change of the produced tubes directly after the process (gray, dark, matt) which is not a defect. The temper colours are removed by passivation.

The eddy current tests were carried out in accordance with the requirements of EN 12084 (EN ISO 15549). They were made using the EDDYCHECK ${ }^{\oplus} 650$ compact with magnetizer, which were mounted directly on the tubes production line. This solution allows for ongoing monitoring of the quality of manufactured products and elimination of tubes sections, which have welding defects. It is also one of obligatory tests (it can be replaced e.g. by radiographic examinations) in the product standard, e.g. EN 10217-7.

No welding defects were detected for the pipes tested.

Subsequently, penetrant tests were carried out in accordance with the requirements of EN ISO 3452-1. On their basis, no welding defects were identified.

Non-destructive testing did not reveal the presence of welding defects. On this basis, the joints were classified at the B quality level according to EN ISO 5817. This indicates a correctly designed welding process in relation to the main variables of the process 142 . The samples were then transferred to the subsequent stages of testing.

\section{Destructive testing}

\section{Static tensile test}

Tensile tests were carried out in accordance with the requirements of EN ISO 6892-1. They allowed determination of the tensile strength $\mathrm{R}_{\mathrm{m}}$, apparent yield point $\mathrm{R}_{\mathrm{p} 0,2}$ and elongation of $\mathrm{A}_{80}$ for all tested tubes (three samples for each solution annealing temperature). The results of the tests are presented in figures 3 and 4 . The conducted research showed that the increase of the solution annealing temperature in the tested range does not significantly affect the decrease of the tensile strength $R_{m}$ and the apparent yield point $R_{p 0,2}$ (Fig. 3). Even with the solution annealing temperature of $1000{ }^{\circ} \mathrm{C}$, which is lower than the minimum required heat treatment temperature by $20^{\circ} \mathrm{C}$, there was no decrease in $\mathrm{Rm}_{\mathrm{m}}$ and $\mathrm{R}_{\mathrm{p} 0,2}$ below the required acceptance criterion $\left(R_{\operatorname{mmin}}=650 \mathrm{MPa}, R_{\mathrm{p} 0,2 \min }=450 \mathrm{MPa}\right)$. For this temperature, the mean value of three measurements was obtained at the level of $815 \mathrm{MPa}$ for $\mathrm{R}_{\mathrm{m}}$ and $572 \mathrm{MPa}$ for $\mathrm{R}_{\mathrm{p} 0,2}$. The increase in the temperature of the solution annealing led to a slight decrease in both parameters for the remaining heat treatment temperatures, however, the obtained values fall within the acceptance criteria established in the subject standards (EN 10088-2, SA 789). Analyzing the results of tests for the elongation of Aso, it was found that along with the increase of the solution annealing temperature the elongation increases (Fig. 4). The values obtained are above the minimum requirements for steel LDX 2101 (at least 30\%), and the recorded values range from $38.9 \%$ to $42.4 \%$. The expected dependence was observed, i.e. with the increase of the solution annealing temperature the tensile strength (though in a small range) and the apparent yield point decrease, and the elongation $A_{80}$ increases. These changes are beneficial provided that with growth of plasticity the required tensile strength is obtained, which is confirmed by the test results. The observed relations are usually a consequence of the homogenization of the austenitic structure. However, it should be remembered that for too low solution annealing temperatures, and thus long homogenization times, it is 
possible to start the formation of precipitation processes, which is disadvantageous from the point of view of the properties of welded joints.

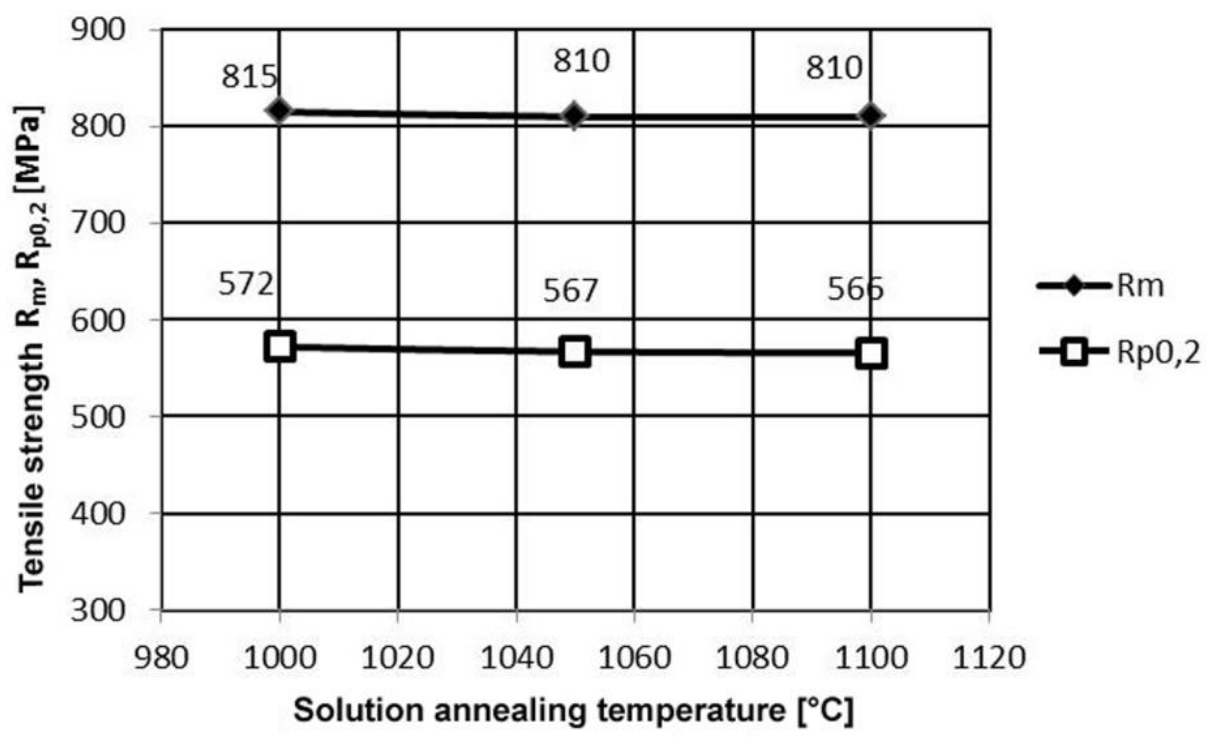

Fig. 3. Relationship of tensile strength on the solution annealing temperature for the tested tubes

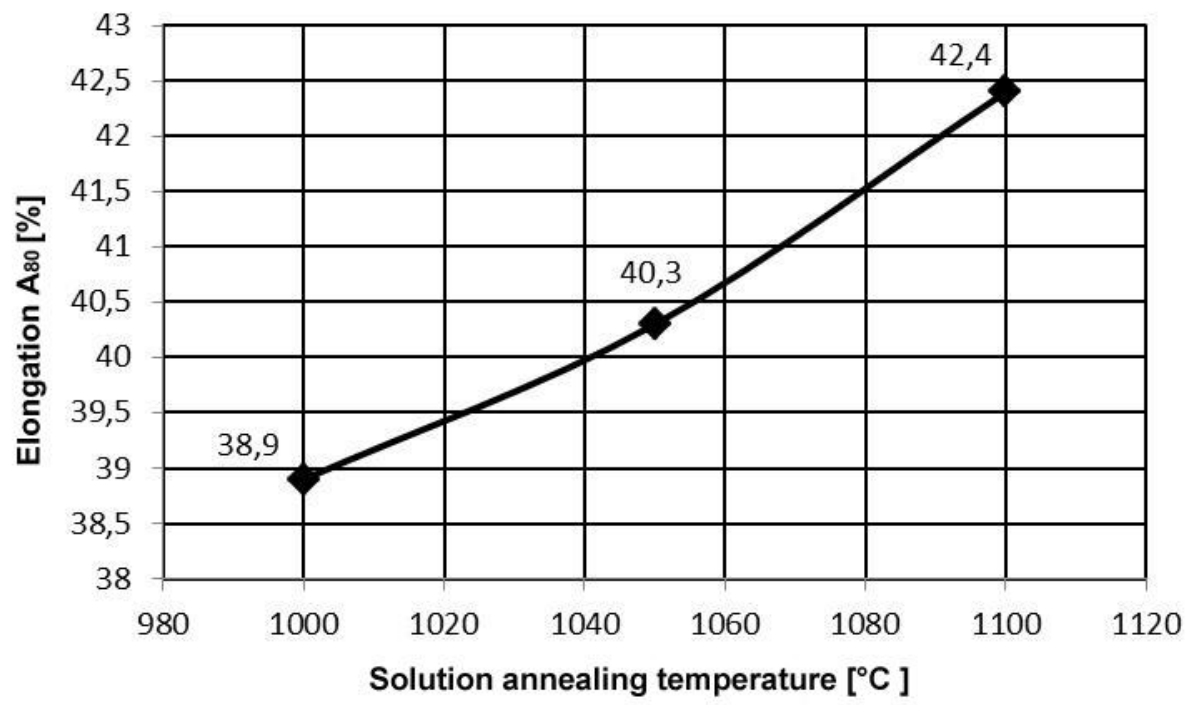

Fig. 4. Relationship of elongation $A 80$ on the solution annealing temperature for the tested tubes

\section{Flattening test}

The flattening test was carried out in accordance with the requirements of EN ISO 8492. Such tests are aimed at determining the susceptibility of round tubes to plastic deformation. The tests were carried out on samples with a length of $60 \mathrm{~mm}$ taken from the tubes. Three tests were carried out for each solution annealing temperature. They were carried out on the MATRA hydraulic press. The samples were placed so that the axis of the weld was halfway up the tube and subjected to the greatest compressive stress. The tubes were plastically deformed until the contact of the surface reached the section corresponding to at least half of the internal width of the sample (in accordance with the requirements of the standard, Fig. 5a). Figure $5 \mathrm{~b}-\mathrm{d}$ shows the tested surfaces. The external side surfaces of the samples subjected to the greatest plastic deformation were evaluated. For the sample, the acceptance criterion is the lack of cracks and tears in the investigated area. No cracks, tears and delaminations were identified in the tested samples. This testifies to the good plasticity of the tested joints and the lack of internal defects, the consequence of which would be cracks. 


\section{Flanging test}

The flanging test was carried out in accordance with EN ISO 8494. The test runs are shown in Figure 6. The MATRA hydraulic press was used for the test. The test conditions were: test temperature $20{ }^{\circ} \mathrm{C}$, flanging force $80,000 \mathrm{~N}$, mandrel's diameter $35 \mathrm{~mm}$, mandrel's angle $35^{\circ}$. The length of the test samples was $60 \mathrm{~mm}$. The length of the cylindrical part after the flanging test was over 0.5D. All samples tested, irrespective of the solution annealing temperature, showed no cracks or tears on the whole circumference of the flange, also in the area of the welded joint. This indicates that the relevant variables of the welding process 142 have been correctly selected. The influence of the solution annealing temperature on the plastic properties determined by the flanging test has not been demonstrated.

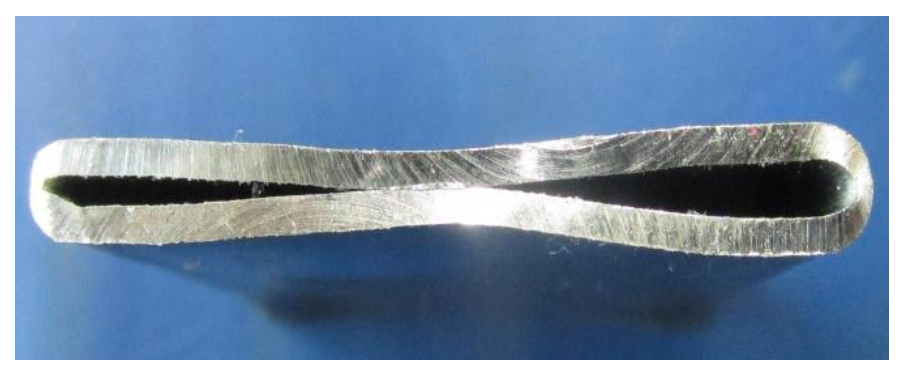

a)

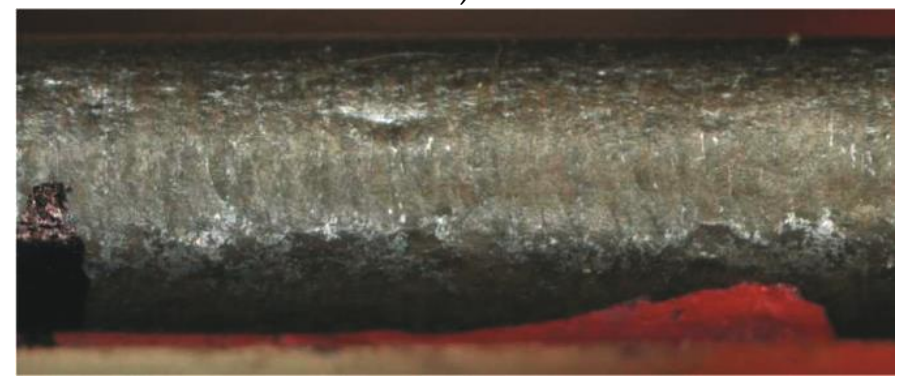

c)

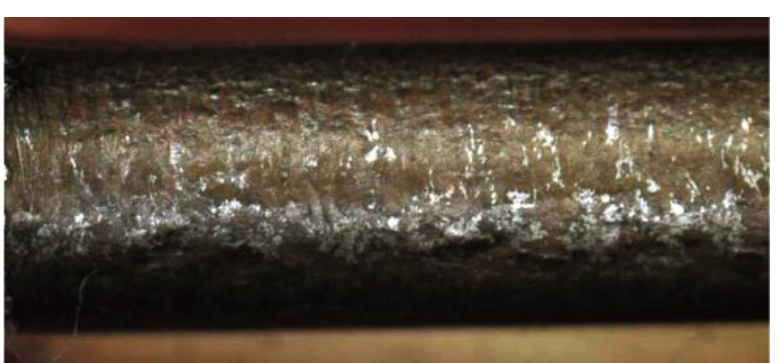

b)

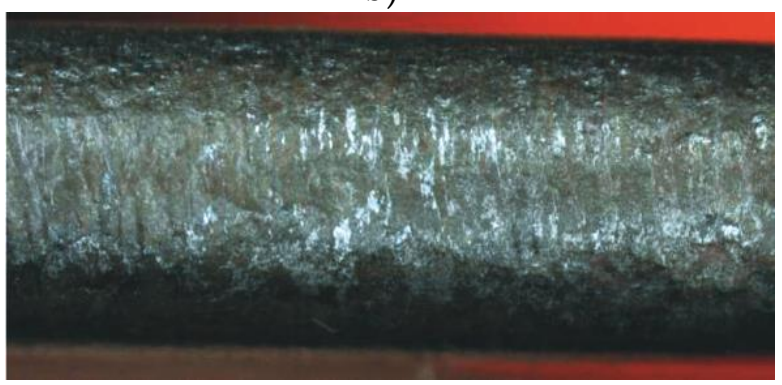

d)

Fig. 5. View of tested welded joints after flattening test: a) cross-section of tested sample with required surface contact, b) test area for $\mathrm{T}=1000^{\circ} \mathrm{C}, \mathrm{c}$ ) test area for $\mathrm{T}=1050{ }^{\circ} \mathrm{C}, \mathrm{d}$ ) test area for $\mathrm{T}=1100{ }^{\circ} \mathrm{C}$

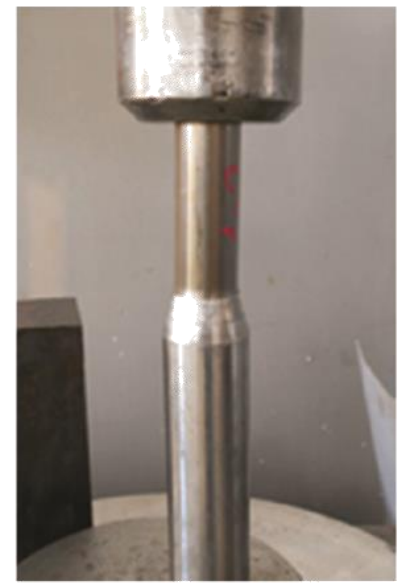

a)

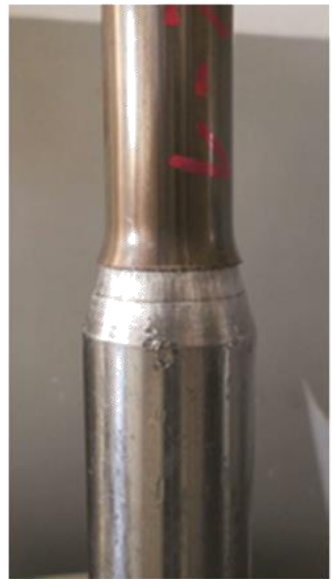

b)

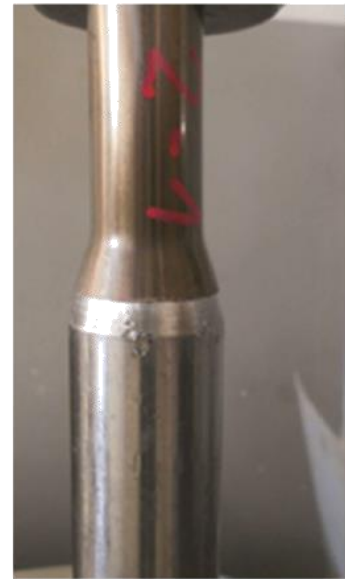

c)

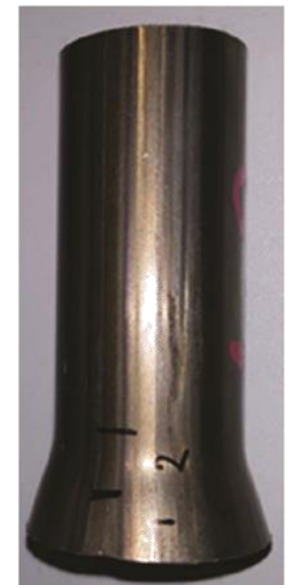

d)

Fig. 6. Flanging test: a) initial step, b) beginning of the plastic deformation step, c) final step, d) the view of the sample after completion of the test

\section{Metallographic macro- and microscopic examinations}

Metallographic macro- and microscopic examinations were carried out in accordance with the requirements of EN ISO 17639. Samples for testing were taken from tubes transverse to the welding direction. The preparation for the research was carried out in several stages. Grinding was carried out using abrasive papers of gradations $400,800,2000,4000$. Then the samples were polished on the polishing cloth using an aluminum oxide paste and etched with MURAKAMI reagent $(100 \mathrm{ml}$ of water, $10 \mathrm{~g}$ $\mathrm{K}_{2} \mathrm{Fe}(\mathrm{CN})_{6}$,

$10 \mathrm{~g} \mathrm{KOH}$ ). Figure 7 shows the macrostructure of the tested joints. Figures 8 and 9 show their 
microstructure in the area of the weld, HAZ and base material. Macroscopic tests showed the correct structure

of the joint with a flat root and face of the weld, which is extremely important from the point of view of the flow of the working medium in the heat exchanger. The walls of the connected elements have been melted correctly. There were no external (geometric) and internal (lack of fusion) defects. This confirms the correct definition of the 142 process variables, including parameters of welding and selection of shielding gases.

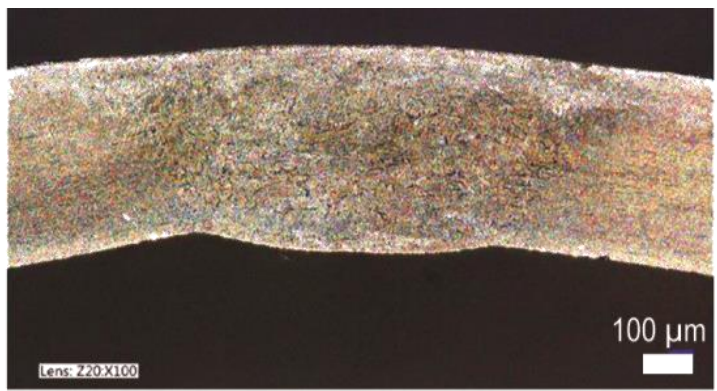

a)

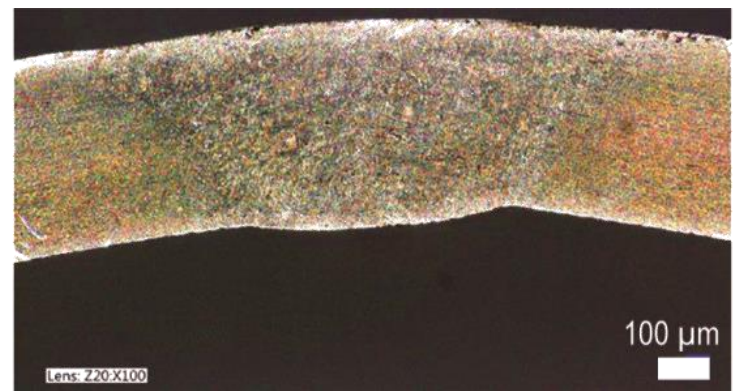

b)

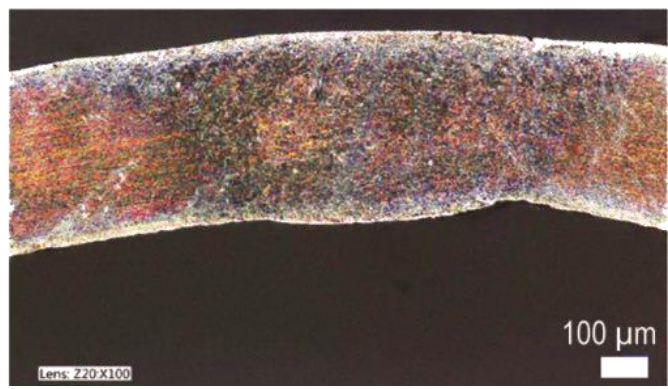

c)

Fig. 7. Macrostructure of butt joints: a) sample $1-1000^{\circ} \mathrm{C}$, b) sample $2-1050^{\circ} \mathrm{C}$, c) sample $3-1100^{\circ} \mathrm{C}$. Etching with MURAKAMI'S reagent

For microscopic metallographic examinations, samples used during macroscopic examinations were used. Based on the performed tests, it can be concluded that the structure of all tested samples is similar. For the austenite etching reagent used, it is white grains, while ferrite is visible in the form of dark fields. In the base material (Fig. 8a, 8b, 8c), a typical banded arrangement of austenite and ferrite grains after the rolling process was observed. Their orientation results from the direction of rolling. It was observed that along with approaching the weld the grain growth occurs, which is characteristic for this area (Fig. 8a, $8 \mathrm{~b}, 8 \mathrm{c}$ ) and results from the heat introduced during welding and then solidification. It can also be seen that for the lowest solution annealing temperature (Fig. 8a) the amount of ferritic phase increases. The heat affected zone is very narrow, and in the area of overheating an increased proportion of ferrite was observed. Clean, local ferritic bands are visible at the transition from the base material to the weld. Observed structures have a typical structure in the welded joint in duplex steel. It should be noted, however, that the effect of the solution annealing temperature changes the proportion of the ferritic phase, which should be shown in the ferrite measurements. For the applied magnifications, no precipitations of chromium carbides on the grain boundaries of austenite were identified, even for the lowest solution annealing temperature, which is $20{ }^{\circ} \mathrm{C}$ lower than the required minimum. During the metallographic microscopic studies, the occurrence of sigma and chi phases was not revealed.
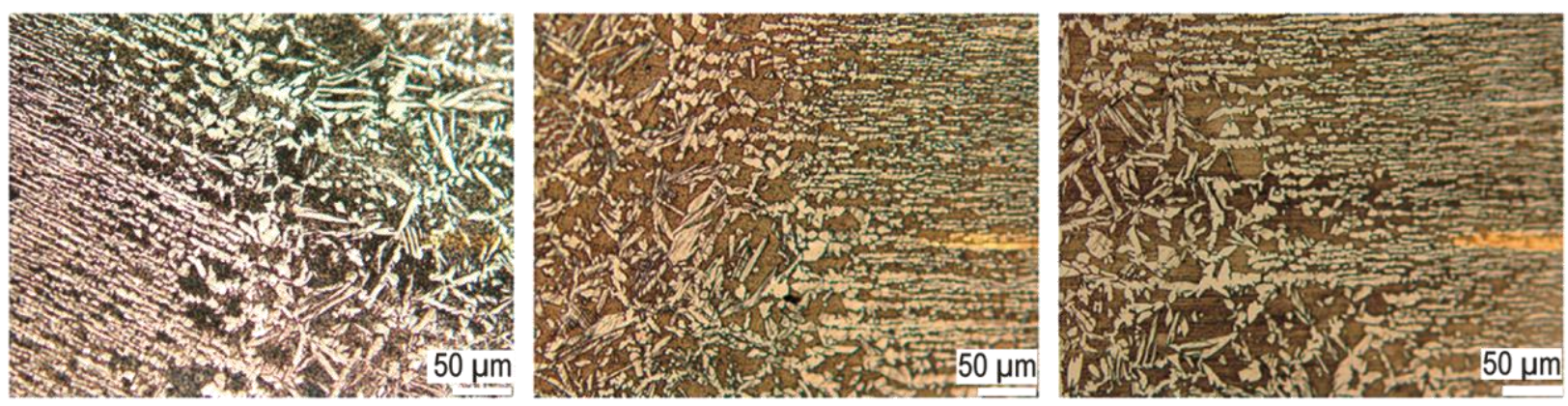
Fig. 8. Microstructure of butt joints of the area: base material - heat affected zone - weld after solution annealing: a) $1000{ }^{\circ} \mathrm{C}$, b) $\left.1050^{\circ} \mathrm{C}, \mathrm{c}\right) 1100{ }^{\circ} \mathrm{C}$

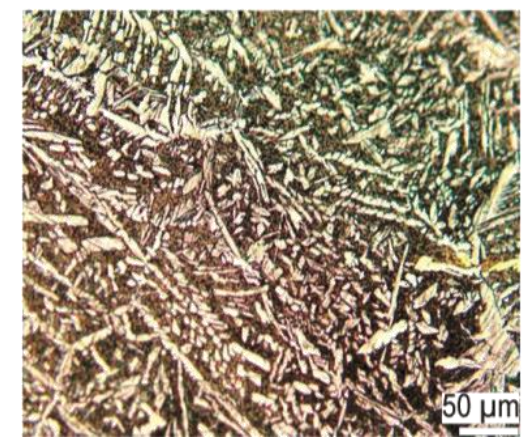

a)

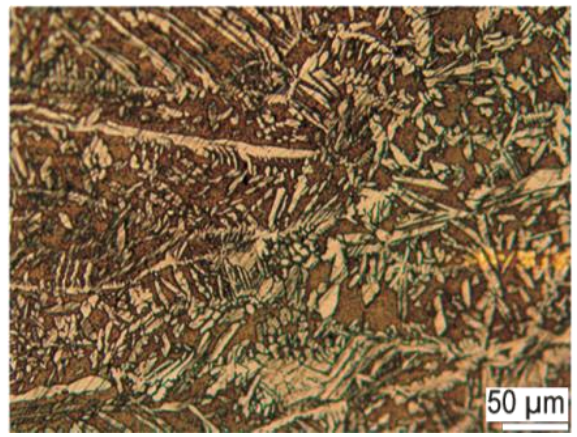

b)

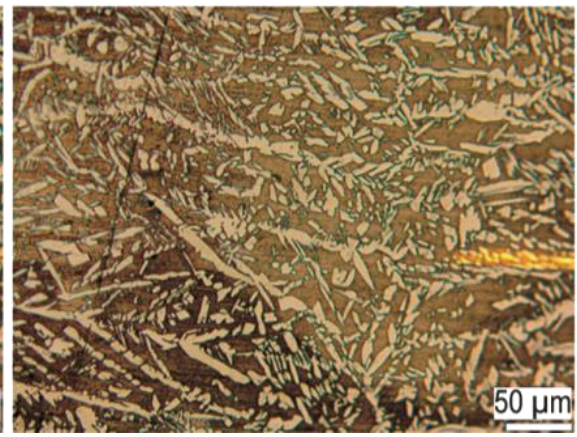

c)

Fig. 9. Microstructure of the weld after solution annealing: a) $1000^{\circ} \mathrm{C}$, b) $1050{ }^{\circ} \mathrm{C}$, c) $1100{ }^{\circ} \mathrm{C}$

\section{Ferrite measurements}

In order to determine the content of ferrite in the weld and the base material, measurements were made using Fisher's feritscope model FMP30. Base material is also subject to structural changes because the tube is annealed throughout the entire cross-section. The criterion of acceptance was ferrite content of $30 \div 70 \%$, which is in line with ASTM E562 and NORSOK M-601. Measurements in the base material and the weld showed that an increase in the solution annealing temperature leads to an increase in the ferrite content in each of the studied areas. This is the result of a large temperature gradient that accompanies intensive cooling in the aquatic environment to ambient temperature. This in turn leads to high cooling rates that favor the formation of large amounts of ferrite. The measurement results are shown Figure 10.

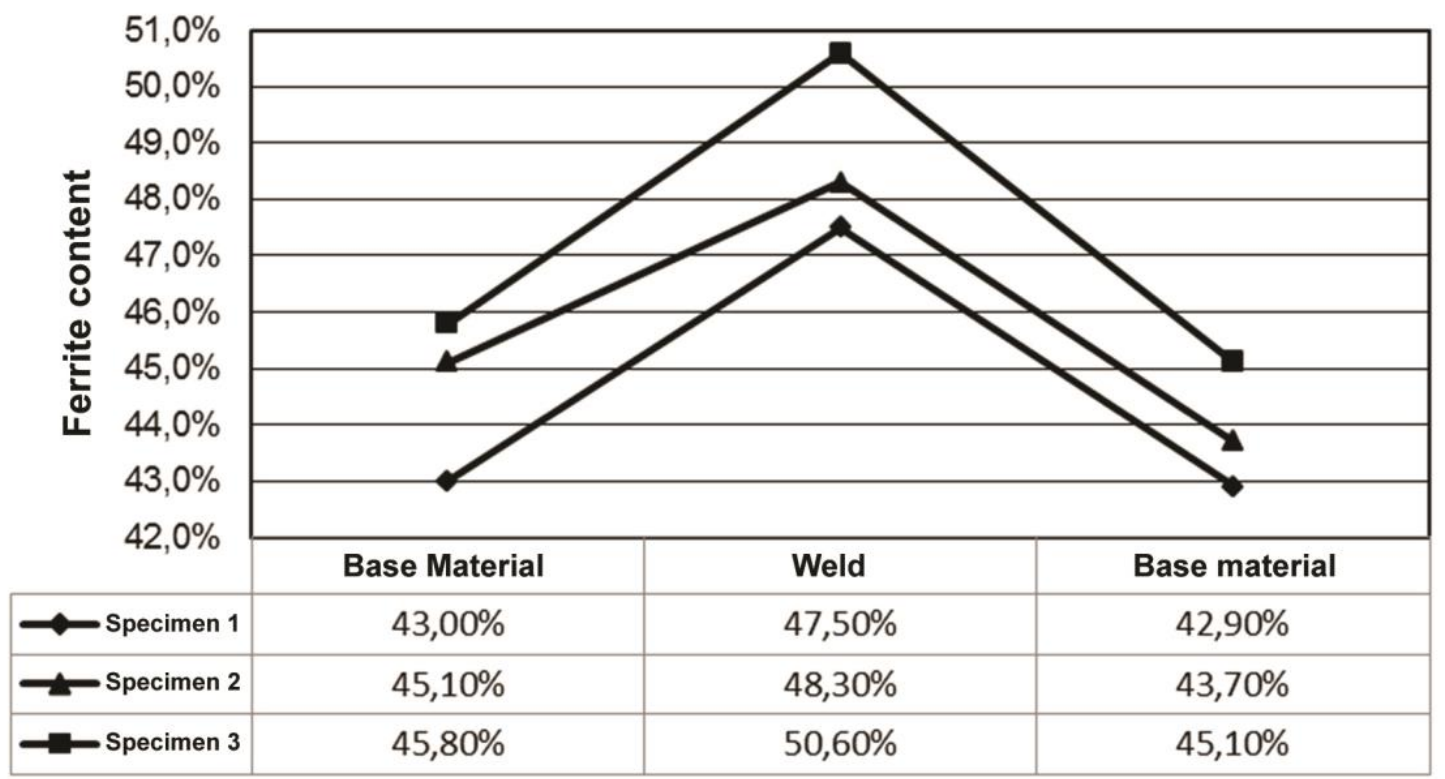

Fig. 10. Influence of the solution annealing temperature on ferrite content in the tested tubes: a) sample $1-1000{ }^{\circ} \mathrm{C}$, b) sample $2-1050{ }^{\circ} \mathrm{C}$, c) sample $3-1100{ }^{\circ} \mathrm{C}$

All results fall within the assumed acceptance criterion. No measurement exceeded the lower limit of $30 \%$, and the lowest measured value was $42.9 \%$ in the base material for sample 1 annealed at $1000{ }^{\circ} \mathrm{C}$. The maximum ferrite content was $50.6 \%$ in the weld of sample 3 . In the case where the material in the delivery condition has a specific ratio of ferrite to austenite content ( $40 \%$ ferrite, $60 \%$ austenite), it can be concluded that all joints in which values of $40 \div 50 \%$ of ferrite should have mechanical and anti-corrosion properties not less than the base material.

The obtained results are consistent with microscopic metallographic observations and confirm the effect of the increased cooling rate of joints, resulting from the cooling effect of water, on the slowing down of the $\alpha \rightarrow \gamma$ transformation. 


\section{Conclusions}

Based on the analysis of the results of the conducted research, the following conclusions can be drawn:

1. The TIG (142) longitudinal welding technology has been developed for $ø 25.0 \times 1.0 \mathrm{~mm}$ tubes used for the construction of tubular heat exchangers with the Lean Duplex LDX 2101 steel. The used technology guarantees the obtainment of joints without welding defects.

2. The use of solution annealing temperatures in the range from $1000{ }^{\circ} \mathrm{C}$ to $1100{ }^{\circ} \mathrm{C}$ affects the mechanical properties of the tubes. An increase in the solution annealing temperature leads to a decrease in mechanical properties $\left(R_{\mathrm{m}}, \mathrm{R}_{\mathrm{p} 0.2}\right)$, but in the range acceptable to the product standard.

3. The increase of the solution annealing temperature in the tested range results in the improvement of plastic properties determined by the Aso elongation.

4. Measurements of ferrite by magnetic method confirm the results of metallographic microscopic investigations. It was found that the increase of the solution annealing temperature leads to the formation of an increased share of the ferritic phase. Independently of the temperature tested, each of the tested samples meets the requirements for this parameter in accordance with the relevant subject standards.

5. It was found that $1050{ }^{\circ} \mathrm{C}$ is the most favorable temperature from the point of view of mechanical and plastic properties.

Acknowledgments: The authors would like to thank SECESPOL LLC for making the test joints, which were used to carry out the tests.

\section{References}

1. Minor T. Analysis of the technical and legal status of gas installations in Poland in terms of the safety of their exploitation - proposals for changes. Nafta-Gaz 11/2017.

2. Mindur M. Processes of extraction and transport of crude oil and natural gas in selected EU countries. Logistyka $4 / 2015$.

3. Szruba M. Pipes in infrastructure. Nowoczesne Budownictwo Inżynieryjne 1/2017, 42-44.

4. Rogalski G.; Łabanowski J. Kwalifikowanie technologii spawania zgodnie z wytycznymi normy PN-EN ISO 15613 na przykładzie wytwarzania rur stosowanych w płaszczowo-rurowych wymiennikach ciepła. Biuletyn Instytutu Spawalnictwa 2011, vol. 55(5), 57-61.

5. Rogalski G.; Fydrych D. Kwalifikowanie technologii spawania wg PN-EN ISO 15614-8 na przykładzie płyt sitowych w U-rurowych wymiennikach ciepła. Welding Technology Review 2012, vol. 84(2), 27-35.

6. Świerczyńska A.; Rogalski G.; Fydrych D. Badania struktury i właściwości spawanych austenitycznych rur wymienników ciepła. Welding Technology Review 2010, vol. 82(6), 11-16.

7. Rogalski G.; Łabanowski J.; Fydrych D.; Świerczyńska A. Wpływ obróbki cieplnej na właściwości spawanych austenitycznych rur wymienników ciepła. Welding Technology Review 2014, vol. 86(6), 24-31. [CrossRef]

8. Ha H.Y.; Lee T.H.; Lee C.G.; Yoon H. Understanding the relation between pitting corrosion resistance and phase fraction of S32101 duplex stainless steel. Corrosion Science 2019, vol. 149, 226-235. [CrossRef]

9. Arabi S.H.; Pouranvari M.; Movahedi M. Pathways to improve the austenite-ferrite phase balance during resistance spot welding of duplex stainless steels. Science and Technology of Welding and Joining 2019, vol. 24(1), 8-15. [CrossRef]

10. Rogalski G.; Prokop K.; Fydrych D.; Łabanowski J. Badania złączy spawanych bimetalu zgrzewanego wybuchowo stali niestopowej Grade 60 ze stopem Monel 400. Welding Technology Review 2014, vol. 86(6), 17-23. [CrossRef]

11. Rogalski G.; Fydrych D.; Landowski M.; Łabanowski J. Weldability of titanium Grade 2 on example of shell and tube heat exchanger. Welding Technology Review 2015, vol. 87 (10), 17-22. [CrossRef]

12. Zhu L.; Chen S.; Yang Y.; Sun Y. Transient heat transfer performance of a vertical double U-tube borehole heat exchanger under different operation conditions. Renewable Energy 2019, vol. 131, 494-505. [Crossref]

13. Łyczkowska K.; Adamiec J. Resistance of welded joints 304 and $304 \mathrm{H}$ to intercrystalline corrosion. Welding Technology Review 2017, vol. 89(9), 31-36. [CrossRef]

14. Lange A.; Białucki P.; Bashir A. Harapińska E.; Małachowska A. Causes of cracks of chemical apparatus made of austenitic steel. Welding Technology Review 2018, vol. 90(12), 25-31. [CrossRef]

15. Górka J.; Grzesica K.; Golda K. Orbital TIG welding of X5CrNi18-10 austenitic stainless steel. Welding Technology Review 2018, vol. 90(5), 55-59. [CrossRef] 
16. Nakonieczna N.; Adamiec J. The tendency to hot cracking of the welded joints of nickel superalloy Inconel 617. Welding Technology Review 2017, vol. 89(5), 17-22. [CrossRef]

17. Kamela A.; Adamiec J. Evaluation of high temperaturę corrosion resistance of hybrid welded membrane walls panels joints of austenitic stainless steel. Welding Technology Review 2018, vol. 90(7), 26-29. [CrossRef]

18. Kiszka A.; Czupryński A.; Baszczyńska E. Effect of shielding-gas nitrogen content on the properties of TIG and ATIG orbital-welded tubular joints made of duplex steel. Biuletyn Instytutu Spawalnictwa w Gliwicach 2018, vol. 62(2), 35-40.

19. Świerczyńska A.; Łabanowski J.; Fydrych D. Effect of linear energy and microstructure on the content of residual hydrogen in welded joints made of superduplex steels. Biuletyn Instytutu Spawalnictwa w Gliwicach 2016, vol. 60(5), 171-178.

20. Souza C.S.; Soares R.B.; de Faria R.A.; Bracarense A.Q.; Castro M.D.M.; de FC Lins V. Effect of heat input on the corrosion resistance of the cold worked 2304 lean duplex stainless steel GMAW welded joint. Materials and Corrosion 2019, vol. 70(3), 409-418. [CrossRef]

21. Mitelea I.; Uțu I.D.; Karancsi O.; Crăciunescu C.M. Investigation of the microstructure of dissimilar welds in duplex stainless steel and low alloyed steel. Materials Testing 2019, vol. 61(2), 120-124. [CrossRef]

22. Łabanowski J.; Prokop-Strzelczyńska K.; Rogalski G.; Fydrych D. The effect of wet underwater welding on cold cracking susceptibility of duplex stainless steel. Advances in Materials Science 2016, vol. 16(2), 68-77. [CrossRef]

23. Arun D.; Ramkumar K.D.; Vimala R. Multi-pass arc welding techniques of $12 \mathrm{~mm}$ thick super-duplex stainless steel. Journal of Materials Processing Technology 2019, vol. 271, 126-143.

24. www.secespol.pl

25. Westin E.M.; Johansson M.M.; Pettersson R.F.A. Effect of nitrogen-containing shielding and backing gas on the pitting corrosion resistance of welded lean duplex stainless steel LDX 2101® (EN 1.4162, UNS S32101). Welding in the World 2013, vol. 57(4), 467-476. [CrossRef]

(C) 2019 by the authors. Submitted for possible open access publication under the terms and conditions of the Creative Commons Attribution (CC BY) license (http://creativecommons.org/licenses/by/4.0/). 